\title{
Making Governance More Participatory at the Local Level in Nigeria
}

\author{
Femi Popoola ${ }^{1}$ \\ ${ }^{1}$ Department of Public Administration, Obafemi Awolowo University, Ile-Ife, Nigeria \\ Correspondence: Femi Popoola, Department of Public Administration, Obafemi Awolowo University, Ile-Ife, \\ Nigeria. E-mail: popefemi@yahoo.com
}

Received: July 1, $2013 \quad$ Accepted: August 27, $2013 \quad$ Online Published: September 1, 2013
$\begin{aligned} & \text { doi:10.5539/jsd.v6n9p101 } \\ & \text { URL: http://dx.doi.org/10.5539/jsd.v6n9p101 }\end{aligned}$

\begin{abstract}
Yearning for good governance in Africa and Nigeria, in particular, has remained a pressing and topical issue. Indeed, governance and development issues are on the front burner in democratizing societies like Nigeria. The crisis of development has been described as a 'crisis of governance' by the World Bank (2003). This crisis of governance has adversely affected the quality and quantity of public utilities provided at the local level. Development strategies of government at the federal, state and local levels have not actively enlisted the participation of Community-Based Organizations (CBOs) in local governance despite their obvious activities and contributions to development in their communities. The bureaucratic institutions of State Administration have become so centralized with the CBOs largely relegated and made irrelevant. It is believed that if the self-governing capacity of $\mathrm{CBOs}$ is harnessed, supported and reinforced by governance structures, socio-economic development will be positively affected and possibly lead to its sustainability. It is against this backdrop that this paper examined the essence of CBOs participation in governance for facilitating and fast-tracking socio-economic development and ensuring accountability and responsiveness among government functionaries. The paper also presented the necessary conditions that must be met for CBOs involvement in governance as well as the expected gains of participatory governance. The paper concluded that participation of CBOs in governance could lead to effective representation and empowerment which would, in turn, enhance democratic dividends at the grassrootsl, especially in the local communities.
\end{abstract}

Keywords: governance, participation, development, community-based organizations, empowerment

\section{Introduction}

Yearning for good governance in Africa and Nigeria, in particular, has remained a pressing and topical issue. Indeed, governance and development issues are on the front burner in democratizing societies. As a corollary to this, there has been growing interest and increasing support for local governance and local development that will involve the participation of grassroots organizations known widely as Community-Based Organizations (CBOs) in developing nations. The crisis of development in Africa generally and Nigeria in particular has been described as a 'crisis of governance' by the World Bank (2003). This crisis of governance has adversely affected the quality and quantity of public utilities provided at the local level. Development strategies of government at the federal, state and local levels have not actively involved the participation of Community-Based Organizations (CBOs) in local governance despite their obvious activities and contributions to development in their various communities. Though bureaucratic institutions of State Administration have become so centralized with the CBOs largely relegated, it is believed that if the self -governing capacity of CBOs is harnessed, supported and reinforced by governance structures, socio-economic development at the grassroots will be positively affected and will possibly lead to its sustainability.

Democracy is generally believed to be an ideal form of governance. This is so, not only because it engenders freedom and social justice, but also because it provides the conducive atmosphere where the government and those who govern can jointly participate in the act of governance. Where there is full blown democracy, development, which, according to Todaro (1982) (as cited by Olasupo, 2000), is the transition from underdevelopment to development in terms of series of steps or stages through which a country must proceed, will be fast-tracked. In fast-tracking socio-economic development, it is imperative to embark on democratizing process. Democratizing process that excludes the CBOs is susceptible to failure. 
In Nigeria, democratizing process dwells on bureaucratic administration and this in turn accentuates monocentric approach where the rulership dominates and excludes the ruled. Consequently, centralization has been entrenched. Making recourse to democratic administration that will engender polycentric approach to governance becomes imperative. Democratic administration, according to Ostrom (1989), is characterized by the following:

a) an egalitarian assumption that everyone is qualified to participate in the conduct of public affairs;

b) the notion that scope of the power of command is to be kept at a minimum; and

c) the concept that all important decisions should be resolved through inclusive forums of resolution.

Looking at these characteristics, it is crystal clear that governance, good governance, cannot be the exclusive preserve of those who govern.

This paper is particularly concerned about the urgent need to integrate the Community-Based Organizations (CBOs) in democratic administration. The objective of this paper therefore, is to argue for participation of the essence of CBOs participation in governance, the necessary conditions for their involvement and the gains of participatory governance.

\section{Conceptual Clarification}

In order to make this study more meaningful, conceptual clarification of governance will be made and the relevance of the concept to the whole study will be clearly articulated. McGinnis (1999) defined governance as the way society, as a whole; manages the full array of its political, economic and social affairs. Oyovbaire (2007) reinforced this definition by declaring that governance is about the use of power and authority to affect the human condition. It enables society to maintain, sustain and improve the quality of life, as well as the transformation of the physical environment. The concept "society" stands out clearly in McGinnis and Oyovbaire explanations of governance. Society manages the full array and society maintains, sustains and improves the quality of life of people and transforms the physical environment. Every society encompasses both the rulers and the ruled. Participation of the ruled (the CBOs) therefore, becomes imperative.

Hyden and Court (2002) explained governance to mean the formation and stewardship of the formal and informal rules that regulate the public realm, the arena in which state as well as economic and societal actors interact to make decisions. The clarification given by Hyden and Court is in tandem with that of McGinnis and Oyovbaire. Societal actors and state interact to make decisions. When decisions are jointly taken by the state and societal actors (which, of course include the CBOs), pressing needs of the grassroots and local communities are addressed and consequently, development is fast-tracked. The self-governing tendency and capacity of the CBOs, if properly harnessed and supported by governance structures, will positively affect socio-economic development at the grassroots.

Lutz and Linder (2004) described "governance" thus:

Good governance is, among other things, participatory, transparent and accountable. It is also effective and equitable. And it promotes the rule of law. Good governance ensures that political, social and economic priorities are based on broad consensus in society and that the voices of the poorest and the most vulnerable are heard in decision-making over the allocation of development resources.

One element of good governance that stands out in the above description is participation. In Lutz and Linder's description, "participatory" is number one element. When governance is participatory, other elements of transparency, accountability, effectiveness and equity will manifest. Without the participation of the ruled, accountability, transparency and effectiveness will be a mirage, especially at the local level. Lutz and Linder (2004) described "Local Governance" as follows:

Local governance comprises of a set of institutions, mechanisms and processes, through which citizens and their groups can articulate their interests and needs, mediate their differences and exercise their rights and obligation at the local level. It requires partnership between local governmental institutions, civil society organizations and private sector for participatory, transparent, accountable and equitable service delivery and local development. It necessitates empowering local governments with authority and resources and building their capacity to function as participatory institutions that are responsive and accountable to the concerns and needs of all citizens. At the same time, it is concerned with strengthening of grassroots democracy and empowering citizens, communities and their organizations such as CBOs and NGOs to participate as equal partners in local governance and local development process. 
Arising from the above description of local governance are certain factors. These factors are participation in governance by the local governmental institution and the civil society organizations, accountability and transparency, equity and responsiveness. These factors are the indices of good governance. Without participatory element, all other indices cannot manifest. It follows then that for good governance to be entrenched (especially at the local level); participation of the citizens in decision-making process becomes imperative.

It is also germane to make a conceptual clarification of Community-Based Organizations (CBOs) here. The National Network of Libraries of Medicine (2007) defined CBOs as organizations, public or private non-profit (including a church or religious entity) that is representative of a community or a significant segment of a community, and is engaged in meeting human, educational, environmental, or public safety community needs. This definition is reinforced by The National Community-Based Organization Network (2011) which explained CBOs as groups that are driven by community residents in all aspects of its existence-the governing body and and staff are largely local residents and their offices are within the communities. Their priority issue centers around problems identification and development of solutions to them. Community residents are intimately involved in leadership positions for various activities ranging from program design, implementation to evaluation. CBOs are also perceived as organizations that provide social services at the local level. They are non-profit organizations whose activities are based primarily on volunteer efforts. They depend heavily on voluntary contributions for labour, material and financial support (Chechetto-Salles \& Geyer, 2006).

Arising from the above, it is crystal clear that CBOs are organizations within communities (that have group identity) and respond to the basic needs of their people through self-help efforts and projects thus continuously contributing to the development of their communities. They possess self-governing capabilities and are not only transparent but accountable to their people.

\section{The Essence of CBOs Participation/ Inclusiveness in Governance}

The main thrust of this paper is that making governance more participatory in Nigeria (especially at the local level) is a sine-qua-non if socio-economic development and democratic governance dividends must be realised. Participation should transcend mere involvement of CBOs in local service delivery. They should be fully integrated into all ramifications of governance at the grassroots administration. This involves participation in policy process-including policy identification, conception, setting agenda, implementation and evaluation. CBOs full participation in governance will not only facilitate and fast-track socio-economic development, it will also ensure accountability, transparency and responsiveness among government functionaries. Evidences abound in various communities across the country where $\mathrm{CBOs}$ have demonstrated their capability in the art of governance. A few examples include sundry cases of local institutions that have been successful in managing community affairs in Nigeria (Akinola, 2003; Awotona \& Akinola, 1996; Olowu, 1999; Akinola \& Akutson, 2001).

It is an underscoring fact that members of community-based organizations understand their communities and their felt needs. They also have passionate interest in the development of their communities. They are primary stakeholders and they have a lot to contribute to the development of their communities. It therefore, behoves the local authority to factor in the inclusion and participation of these community organizations in their local administration. With joint participation in local governance, local accountability will be ensured.

Another essence of participatory governance at the local level is that the community-based organizations own their communities as well as the functionaries in their local authorities. For the functionaries in the local authorities to meet local needs, they need to partner with CBOs who understand better the pressing needs of their respective communities. No meaningful impact will be made by any local authority that excludes the involvement of the CBOs. Their commitment, expertise and self-governing tendencies should be harnessed by the local authority for all-round success.

Mention must also be made that for any local authority to be effective in its task of developing the local community, the community-based organizations become indispensable. The CBOs are one key pillar (among others) that the local authority requires to be efficient and effective in the discharge of its governance duties. The local authority needs to evolve a strategy that will bring the local organizations into a partnership that is not only constructive, but also devoid of super-ordinate-ordinate relationship. The CBOs could be involved at three major levels which could be broad or narrow. The typology of citizen participation enunciated by Moynihan (2003) can be adopted for the CBOs participation in governance at the local level: 
Typology of Citizen Participation

\begin{tabular}{|c|c|c|}
\hline \multicolumn{3}{|c|}{ Representativeness } \\
\hline Level Full & Broad & Narrow \\
\hline Decisions & $\begin{array}{l}\text { Public officials make decisions } \\
\text { But citizens have strong influence }\end{array}$ & $\begin{array}{l}\text { Public officials and selected } \\
\text { Interest groups make decisions }\end{array}$ \\
\hline Participation & $\begin{array}{l}\text { Large, diverse groups of citizens } \\
\text { Engage in meaningful discourse } \\
\text { With government }\end{array}$ & $\begin{array}{l}\text { Interest groups exert significant } \\
\text { influence; most citizens lack } \\
\text { Opportunities to participate }\end{array}$ \\
\hline \multicolumn{3}{|l|}{ Partial } \\
\hline Decisions & $\begin{array}{l}\text { Public officials make decisions; } \\
\text { Citizens have limited influence }\end{array}$ & $\begin{array}{l}\text { Government elite make decisions; } \\
\text { Interet groups have limited influence }\end{array}$ \\
\hline Participation & $\begin{array}{l}\text { Large diverse groups of citizens } \\
\text { Engage in limited discourse with } \\
\text { Government }\end{array}$ & $\begin{array}{l}\text { Interest groups exert influence; } \\
\text { most citizens lack opportunities to Participate }\end{array}$ \\
\hline \multicolumn{3}{|l|}{ Pseudo } \\
\hline Decisions & Public officials make decisions & Public officials make decisions in Non-transparent manner \\
\hline Participation & $\begin{array}{l}\text { Participation is symbolic but } \\
\text { Involves large, diverse groups } \\
\text { Of citizens }\end{array}$ & $\begin{array}{l}\text { Participation is symbolic, } \\
\text { involving only a small number } \\
\text { Of citizens }\end{array}$ \\
\hline
\end{tabular}

Source: Moynihan, 2003.

CBOs participation in governance could be at any of these three major levels. The participation could even start at pseudo level (broad or narrow) and move up gradually to full level. What is fundamental is that CBOs should be engaged in participatory governance with the local authorities.

\section{Fostering Involvement of CBOs in Governance}

The idea of local governments/local authorities involving local communities in governance and service delivery is not an entirely new thing. Public Administration scholars and practitioners have clamoured and still clamour for the running of governmental affairs and service delivery through collaboration and co-production in line with the public choice school. This was engendered by the apparent failure of the State to meet the basic needs of its citizens which itself is an offshoot of the crisis of governance.

Some necessary conditions must be met for constructive and effective participation of local organizations and local authorities in local governance. The submission of Council of Europe (2005), in this regard, will suffice.

Firstly, there should be information sharing between the local authority and the various local organizations. Information sharing will not only create the necessary awareness, it will also keep the community people informed. Besides, transparency and legitimacy of the local authority are built. In sharing information, the two groups have respective roles to play. The local authority should distribute and disseminate relevant document that chronicle its activities to the local organizations through the media. The local people too should generate and provide various relevant information and data that could be of immense help to the local authority. Information sharing must be done on a sustainable basis between the two parties.

Secondly, regular consultation with the local people and organizations should be embarked upon by the local authority. This entails getting feedback from the local people and organizations on the kinds and qualities of services provided as well as the budgetary plans of the local authority. Town hall meetings and other forms of beneficiary assessment meetings should be held for the purpose of consultation.

Thirdly, regular consultation should be followed up with joint participation in decision-making. The local authority needs to set up that mechanism that will enable the local people and organizations to participate in decision-making. The two parties must share control over decision-making. Local joint committees comprising members of the local authority and local organizations could be set up to look into the budget proposal of the local authority as well as social services to be provided. Local people's knowledge, ability and experience could be harnessed through this participation.

Fourthly, the strategy of collaboration by the two parties involved must be adopted. Local people and organizations should be included in various problem-solving activities - design, implementation and evaluation of projects. Again, the knowledge, ability and experience of local citizens will come into play. Many of them are professionals in their rights and they could bring their professional competence and experience to bear on the 
development of their communities. For instance, professional builders could be brought in for collaboration in building and construction activities. The youths, also could be involved in security services by working with the police. They could also be engaged in revenue sourcing mobilization and generation such as poll tax.

Fifthly, the mechanism of empowerment needs to be adopted. Empowerment in this regard means that the local authority should transfer decision-making control (in some areas), fund and implementing activities to the local organizations. If this is done, it will typify what democracy is all about. Various management committees on the local natural resource could be set up comprising community members. Each committee will work on each natural resource. Apart from this, workable partnership of different kinds could be established. This will empower community people. Good governance will only exist, in concrete terms, when citizens become empowered to meaningfully participate in decision-making process.

\section{The Gains of Participatory Governance}

The local authority, community-based groups, the entire communities and the system as a whole stand to gain from participatory governance.

Firstly, participatory governance will enhance the enthronement of democracy and its sustainability. When there is participation, democracy will find its feet. This, in turn, will lead to more participation and more democracy. In a democratized setting, implementation of policies will be effective and efficient. Apart from this, democratic legitimacy will be understood for the local government.

Secondly, participatory governance will engender equity. More participation will lead to greater equity. Various communities make up particular local government areas, each with its peculiar and pressing needs. As greater participation is established, there will be greater responsiveness to the pressing needs of the various communities in an equitable manner. Services will be evenly distributed and everybody, every community will be happy.

Thirdly, accountability and transparency will be established where there is participatory democracy. One major problem confronting our local government system today is lack of accountability and transparency. Fund is often mismanaged, misappropriated or outrightly embezzled. With greater participation of community people in governance, accountability will be ensured and transparency will be the motto of everybody. Fund will not only be judiciously handled, but expended and there will be development in concrete terms.

Fourthly, participatory democracy will bring about greater development of a more active civil society. The civil society under discussion is located in the fifth category of Abutudu (1995) classification. It is made up of numerous groups that are voluntary in nature and are essentially supportive in character. These community-based groups do cater for the basic needs of the people effectively and efficiently when the state is failing to meet the basic needs of the people. Members of these community-based groups are knowledgeable, experienced and endowed in various ways to tackle problems and challenges of development facing them and their people. With their inclusion in participatory governance, they will be developed to be more active not only in partnering with the local authority in service delivery, but also in taking joint decisions and implementation of policies. They will become involved and responsible local citizens.

Fifthly, the quality of local services will be enhanced when there is participatory governance. The greater the participation of the local people in governance, the better the quality of local services that are provided. This is because the knowledge, experience, technical know-how and proficiency of community members will come into play in determining contractors to use and ensuring quality control through proper monitoring of service delivery. Indeed, the gains of participatory governance cannot be over-emphasized.

\section{Concluding Remarks}

This paper discussed making governance more participatory in Nigeria, especially at the local level. The paper advanced arguments for the participation/inclusion of community-based organizations at the grassroots. It further presented the essence of CBOs participation in governance and discussed the necessary conditions for their inclusion as well as reiterated that participation of CBOs in governance has become not only imperative but impelling in order to fast-track socio-economic development of local communities. With the practice of participatory governance, the CBOs' will, ability and capability in organizing themselves will not only be enhanced but also be more articulate in their demands and they will implement policies jointly with the local authority officials and other public agencies. This conclusion corroborates the submission of the Council of Europe (2005) on participation which interalia states that: "The more experience individuals and groups have in participating, the more likely they are to develop enduring patterns of mutual trust, to mobilize around issues, to engage in collective action, and to be successful in securing a place and influence in the democratic process/system. This will, hopefully, lead to empowerment and socio-economic development". 


\section{References}

Abutudu, M. I. M. (1995). The State Civil Society and the Democratisation Process in Nigeria. Dakar: CODESRIA Monography Series. 1/95.

Akinola, S. R. (2003). Ensuring Public Accountability Through Polycentric Governance Systems at the Local Level in Nigeria. In E. O. Ezeani (Ed.), Public Accountability in Nigeria: Perspectives and Issues (pp. 379-395). Enugu: Academic Publishing Company.

Akinola, S. R., \& Akutson, S. K. (2000). Community Participation in Urban Poverty Reduction: A Case Study of Olaleye-Iponri Community in Lagos Mainland Area, Lagos State, Nigeria. Paper presented at the $10^{\text {th }}$ Annual Conference of Population Association of Nigeria (PAN), University of Lagos. 14-17 October, 2001.

Awotona, A., \& Akinola, S. R. (1996). The Participation of Women in Housing and Community Development in Africa: A Case Study of Nigeria. In M. K. Emine (Ed.), Housing Question of the "others", Chamber of Architects of Turkey (pp. 106-115), Ankara, Turkey.

Chechetto-Salles, M., \& Geyer, Y. (2006). Community-Based Organization Management. Pretoria: Institute for Democracy in South Africa (IDASA).

Council of Europe. (2005). Toolkit of Local Government Capacity-Building Programmes. Strasbourg.

Hyden, G., \& Court, J. (2002). Comparing Governance across Countries and Overtime: Conceptual Challenges. In D. Olowu, \& S. Sako (eds), Better Governance and Public Policy. Capacity Building for Democratic Renewal in Africa. Kumarran Press.

Lutz, G., \& Linder, W. (2004). Traditional Structures in Local Governance for Local Development (pp. 17-18). Berne, Switzerland: University of Berne.

McGinnis, M. D. (1999). Introduction. In Micheal, F. McGinnis (Ed.), Polycentric Governance and Development. Reading from Workshop in Political Theory and Policy Analysis (pp. 1-3, 24). The University of Michigan Press.

Moynihan, D. P. (2003). Normative and Instrumental Perspectives on Public Participation: Citizen Summitsin Washington, D.C. American Review of Public Administration, 33(2), 164-188. http://dx.doi.org/10.1177/0275074003251379

National Community-Based Organization Network. (2011). What is a Community-Based Organization (CBO)? University of Michigan. Retrieved from www.sph.umich.edu/ncbon.whatis. Accessed 27/8/2013

National Network of Libraries of Medicine. (2007). Community Based Organization Defined. Baltimore, USA. Retrieved August 27, 2013 from www.nnlm.gov

Olasupo, F. A. (2000). Community Participation in Governance and Development in Nigeria. A Contemporary Local Government Perspective from Nigeria. Lagos: Malthouse Press Ltd.

Olowu, D. (1999). Local Organizations and Development: The African Experience. Readings from the Workshop in Political Theory and Policy Analysis. Ann Arbo: The University of Michigan Press.

Oyovbaire, S. E. (2007). The Crisis of Governance in Nigeria. A Convocation Lecture Delivered on the $23^{\text {rd }}$ Convocation Ceremony of the University of Port-Harcourt, Nigeria on $15^{\text {th }}$ March. Pp.5, 7, 21, 22.

Ostrom, V. (1989). The Intellectual Crisis in American Public Administration. Tuscaloosa, Alabama: The University of Alabama Press.

Todaro, M. P. (1982). Economics for a Developing World (2 ${ }^{\text {nd }}$ ed.). U.K. Longman Group Ltd.

World Bank. (2003). World Development Report 2004: Making Services Work for Poor People. Washington: World Bank. http://dx.doi.org/10.1596/0-8213-5468-X

\section{Copyrights}

Copyright for this article is retained by the author(s), with first publication rights granted to the journal.

This is an open-access article distributed under the terms and conditions of the Creative Commons Attribution license (http://creativecommons.org/licenses/by/3.0/). 